\title{
EDUCATION MANAGEMENT PERSPECTIVES PROPHET IBRAHIM
}

\author{
Sulistiawati \\ tia.sulistia13@gmail.com \\ Danial Hilmi \\ danialhilmi@gmail.com \\ Universitas Islam Negeri Maulana Malik Ibrahim Malang \\ Jalan Gajayana 50 Malang
}

\begin{abstract}
It is important to emulate the education management perspectives prophet Ibrahim, where management of education has existed since the time of the prophets and the nature of management has existed and has grown naturally since the existence of this life. We first learned management from the time of the Prophet Adam to the time of the Prophet Muhammad. Here researchers focus more on the education management perspectives prophet Ibrahim. As mentioned in the Qur'an, it is emphatic that God established the Prophet Ibrahim with the nickname as "Father of the Prophets" which is a role model for Muslims to navigate life in this world. On the other hand prophetic management is a management model that is encouraged by the values of the Qur'an and the values exemplified by the Prophet directly. In fact, the elements of management have been described in the Qur'an through symbols such as the caliph, and also the hadith of the Prophet. One of them is the self-image of the Prophet Ibrahim through the nature of: honesty, trustworthy, truth, delivery of intelligence, compassion, patience, example, and democracy. So it should be from us to follow every step of his journey.
\end{abstract}

Keywords: Management, Education, Prophet Ibrahim

\section{INTRODUCTION}

The development of management is not much different from the human development, in the history of Islamic civilization since the time of the prophet there has been management, and the essence of the management exists and grows naturally since the existence of this life. There was management since the days of the Prophet Adam, the Prophet Noah, the prophet Joseph, the Prophet Ibrahim and Ismail, and the Prophet Muhammad SAW. The first time we learned from the time of the Prophet Adam was from the story of the opposition of Qabil and Abel that ended in murder, until the time of the Prophet Mohammed. Here researchers focus more on the management of the Prophet Ibrahim.

As we know, the name of Prophet Ibrahim is the name that we always call in our prayers especially in the last Tahiyat there are two names of prophets that we always call namely Prophet

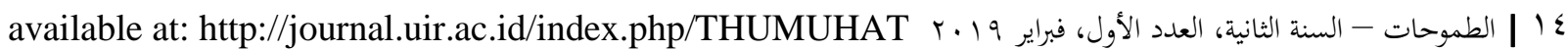


Muhammad and Prophet Ibrahim. And it turns out that the face is similar, not only from the extraordinary, but also from the appearance. ${ }^{1}$

The management of the Prophet Ibrahim can be learned from the event of "Qurban" recorded in the Qur'an. Although the Prophet Ibrahim received orders from God to Slaughter Ismail, his beloved son, but the prophet Ibrahim did a dialogue that was dialogist, before making the decision to slaughter his son. Leadership was part of the management, and the dialogue between Ibrahim and Ismail before he made decisions was part of the management processes. Here we can take the example that the commandment to the prophet is not imposed but is offered.

From a great theme about the education management perspective Prophet Ibrahim, we know that education is a major foundation in a life, where education should have been implanted early in the first place in the education of Islam itself which is a guideline in life. Ideally, Islamic religious education in bringing its roles and functions as well as facing the life dynamics of the nation must be managed with prophetic management. ${ }^{2}$ Management is important in managing all things, including in the Islamic education itself. On the other hand, prophetic management is a model of management being energised by the values of the Qur'an and the values modeled directly by the Prophet and the view of scientists who are in line with the two sources.

In fact, the elements of management have been depicted in the Qur'an through symbols such as the Caliph, and also the hadith of the prophet, such as when on a journey done three people then lift one of them into a leader, not to mention the Prophet describes himself through the nature of trust, Fathanah, Siddik and Tabligh that must be owned by the leader and personality, Intelligent/Clever making planning; coordination and directing. These values exist in Islamic teachings, but this value is less bioavailable and not a major value in the life of a Muslim in managing an educational institution.

\section{EDUCATION MANAGEMENT PERSPECTIVES PROPHET IBRAHIM}

It is appropriate for us to emulate the education management perspective Prophet Ibrahim, how the Prophet Ibrahim was able to deliver his son Ismail become a devout and obedient generation of the command of Allah SWT. This story is enshrined in the Qur'an letter of Abraham

\footnotetext{
${ }^{1}$ Manajemen Nabi Ibrahim AS Oleh Ustadz H.Hendri Tanjung, Ph.D, dikutip dari youtube pada 21 Desember 2019 pukul 15:00

${ }^{2}$ Pendidikan keagamaan Islam, seperti Taman Pendidikan al-qur'an, Diniyah dan Pesantren tertera dalam UU No. 20 Tahun 2003 Tentang Sistem Pendidikan Nasional dan Peraturan Pemerintah No. 55 Tahun 2007 Tentang Pendidikan Islam dan Pendidikan Keagamaan Islam. Lihat UU No. 20 Tahun 2003 Tentang Sistem Pendidikan Nasional,"n,d.

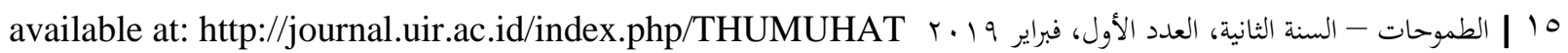


verses 37. From this verse, you can take some lessons on how to educate the Prophet Ibrahim's son, who is placing a descendant in the valley near Baitullah. " In the present context, the child needs to be called a good environment, namely the mosque. For the children to grow up in the atmosphere of worship to God, and that they should make prayers, because prayer is the essence of the education process. Peace will shape one's soul and behavior. If the prayer is good, then all sides of the Islamic will be good.

The child must also be educated in the morals and manners so that the human heart becomes sympathetic and interested. Children need to be equipped with skills to try to find halal sustenance, from the sustenance they can be grateful by helping others and benefiting humanity. In the Qur'an, God himself firmly establishes the Prophet Ibrahim who is nicknamed as the ' father of the prophets ' as the example of the Muslims, in the life of this world.

And when traced this glorious family journey, so many lessons can be taken from every segmentation of life through. Then here the author will display the three fundamental characters of the Prophet Ibrahim: the first; Ibrahim and a typical family of servants who totality in exercising obedience to God. When descending on a commandment to them, it is shown according to the ' Porsi'nya. $100 \%$ without being reduced to any item. Although it is very heavy, and contrary to conscience. There are at least two events depicting it. Firstly, when descending orders to put Hajar, his wife, and Ismail who are still in the cradle, in a valley that has no nuance of his life. A barren Sahara.

incredible, the head of the family who is not sad, in the moment of love, love and affection are in the self, for so long awaits his presence. In a sudden, the orders left them in the place where the plants were reluctant to live. Alone. Logically there is no guarantee of life. However, history noted, Ibrahim and his family were able to run it. What is this form of a servant's obedience to his lord. Worship is also the one who is asked by God to each of his servants, until they have luck, at a later date.

The second event, coming when the boy (Ismail) had grown up adolescent/adult. Back came the test from God. More awesome than the first. Ibrahim asked to slaughter the child. With his own hands. The Prophet Ibrahim was asked to sacrifice the child, by slaughtering it. But, the history of Ink history records, Ibrahim and family were able to fulfill this commandment perfectly. There is no doubt of them to carry out the commandment of God, according to what is requested. In order to 
achieve his ridha. All binding humane feelings are being struck. It is all because, their submission to God, has been for everything they have, no exception to the family, even self-merekaa himself. ${ }^{3}$

This is among the lessons of the Prophet Ibrahim's path. For those of us who expect a similar position, for personal or family, it is a necessity for us to follow every step of his journey, as the appeal of God.

In the context of Islamic education, faith is the fundamental value of Islamic education. This means that Islamic education should be a vehicle for increased faith and taqwa of students. Therefore, all experts of Islamic education agree that the faith becomes a major base in the purpose of Islamic education. The Imam Gazali, for example formulating the purpose of education is to draw closer to God. ${ }^{4}$

character values also included an integral part (inherent) in the context of Islamic education to be transformed, internalized and socialized in the students, both on the intended goal, the material to be delivered, The method that will be used, the environment that will form it or in its hidden curricullum. ${ }^{5}$ In the verses of the Prophet Ibrahim's story, there are many moral values that we can refer to as lessons in the reality of everyday life. The following discussion will further discuss the values of the Prophet Ibrahim's morality, including: Honesty, trustworthy, delivery of Truth, Intelligence, affection, survival, transparency, and democracy.

\section{Honesty}

Al-Jurjani in al-Ta'riat defines honestly as a true word despite being in a malaginated area. $^{6}$ Honesty is the main foundation of the true values of righteousness because honestly it is identical with the truth. In the Prophet Ibrahim's story, the Qur'an explicitly confirms that the Prophet Ibrahim included an honest Prophet (QS. Maryam (19): 41. And the interesting thing is when the Prophet Ibrahim finished destroying the statues, then happened dialogue, as depicted on the QS. Al-Anbiya ' (21): 63, as follows: (They asked: "Do you, who do this deed against our gods, hey Ibrahim? " Ibrahim replied: "Yes, this is great. Ask the idols, if they can speak).

\footnotetext{
${ }^{3}$ https://www.hidayatullah.com/kajian/oase-iman/read/2018/08/23/149161/tiga-karakter-mendasar-kemuliaan-keluargaibrahim.html, dikutip pada 21 Desember 2019 pukul 19:20

${ }^{4}$ Muhaimin dan Abdul Mujib, Pemikiran pendidikan Islam, (Bandung; Rosdakarya, 1993), hlm. 162-163

${ }^{5}$ Zainol Hasan, "Nilai-Nilai Pendidikan Pada Kisah Nabi Ibrahim”, Nuansa, Vol. 14 No.2 Juli, 2017, hlm. 432

${ }^{6}$ Al-Jurjani \& al-Ta'Rifat, (Beirut: dar al-kutub al-Ilmiyah,1988), hlm.132

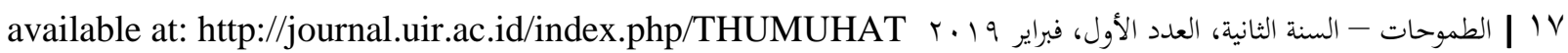


That is a few examples of Prophet Ibrahim's honesty that he could not lie because of honesty, including a character that must be possessed by the Apostles, as God also confirms that the Prophet Ibrahim is an honest Prophet.

\section{Trusted}

Trust is an important element and determines the success and absence of a person in the effort and charity, and the success and absence of a nation in sustaining and preserving life. In everyday life, there is a noticeable difference between a trustworthy person and a person who likes betrayal. A person who is in order or honest is always a place of trust, respect and respected. While the person who is treacherous or cheating is always hated and excommunicated in the association.

In the life history of the Prophet Muhammad SAW, stated that before being appointed prophet, he has been known to the nature of trust so given the title of Al-Amin, which is believed. When the Kaaba was repaired because it was damaged by flooding, the tribal leaders were scrambing to lift and put the black stone into place. At that time, there was almost a bloodshed. But because of the trust nature of the prophet, each tribe entrusted to Muhammad to overcome it, and the event culminated in the satisfaction of all parties (happy ending). In his face he said: "It is not perfect the faith of a person who has no trustful nature." (H.R. Thabrani).

In the context of the Prophet Ibrahim's story, the nature of this mandate is very visible when he had to convey the obligation of God to be in order, and he was in a community and environment that was very not supporting him, including to his own father.

\section{Delivery of righteousness}

In the story of Prophet Ibrahim, it is very apparent how his efforts to convey the treatise of Ketauhidan, even though he faced his own father. Prophet Ibrahim's volume in preaching was seen when he faced his people and his king at once. It is noteworthy how the psychological condition of the Prophet Ibrahim under the hegemony of Namrudz's harsh powers, certainly, the threat is soul. This condition became the anti-climax, namely the burning event of Ibrahim.

\section{Clever}

Clever or Fathonah, in language means, intelligent, clever, clever. ${ }^{7}$ The nature of Syaja'ah can be seen as a life strategy of every Muslim. A Muslim must optimize all the

\footnotetext{
${ }^{7}$ Attabik Ali dan A. Zuhdi Muhdlor, Kamus Kontemporer Arab Indonesia, (Yogyakarta: Multi Karya Grafika, 1998), hlm. 1399

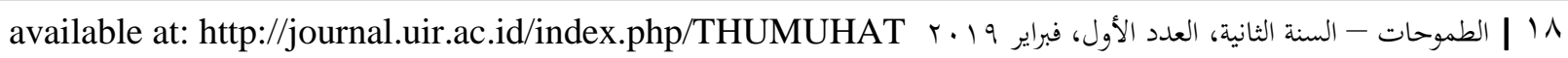


potential that Allah has given to reach the Khaliq. The most valuable and costly potential that is only given to man is reason or intelligence (intellectuality). ${ }^{8}$

In the context of Islamic education, intelligence includes one of the factors for the success of children educated in acquiring science, in Ta'lim al-Muta'allim by Imam al-Zarnuji, stated: ${ }^{9}$ Remember, you will not acquire science Except (as is) six things: 1) intelligence (inteligence quotient), 2) Spirit (Emotional quotient), 3) Patience (spiritual quotient), 4) capital (facilitation), 5) The presence of guidance, 6) a time or a broad opportunity.

In the context of the Prophet Ibrahim's story, among the mandatory traits that the apostles must have is the nature of Fathonah (intelligent). This nature of Syaja'ah appears in the Prophet Ibrahim, with the following description: First, the nature of clever is conferred by God. The granting of capital intelligence to this prophet Ibrahim in the Qur'an is called Rushd. Second, the logic intelligence Prophet Ibrahim. When he was the age of the children, he always thought, how a man who made sense to make a statue with his own hand, then bow and worship him. "Did not worship something of his own that could not do anything is illogical?" asked the Prophet Ibrahim in his heart. Third, intelligence in the utilization of momentum. When held a massive party ceremony by the river and everyone in the city will depart there. In this quiet situation, Ibrahim AS. Have the opportunity to carry out his and his servants plans before the townspeople return.

Fourth, the intelligence of diplomacy. When the Prophet Ibrahim destroyed the worshiped idols, he intentionally let the greatest idols remain intact and drape the axe used as a destructive tool to the idol's neck. Fifth, intelligence captures the wisdom behind the phenomenon. When the Prophet Ibrahim was engrossed Ma'syuq worship star, the Prophet Ibrahim did contemplation, as illustrated in the QS. Al-an'am (6): 76-79. The result of this contemplation is the intelligent conclusion, namely that the Lord is the creator of Heaven, Earth and which includes the two, then he is actually Dzat that must be worshipped, not statues, stars or others as they are.

In the context of modern science, intelligence as above, in psychology referred to by spiritual intelligence (spiritual quotient), in a philosophy called the Transcendental Consciousness, in physics is called the consciousness of the omnipotent existence, in The

\footnotetext{
${ }^{8}$ http://midwiferyenterpreneurship.blogspot.co.id/2013/09/fathanah-nabimuhammad-saw-seorang.html, dikutip pada 21 Desember 2019 pukul 19:45

${ }^{9}$ Burhan al-Islam al-Zarnuji, Ta 'lim al-Muta'allim Thariq al-Ta'allum, (Surabaya: Salim Nabhan, tt), hlm. 15

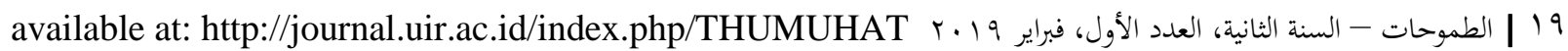


psychology of religion called the consciousness of primordial treaty, in social sciences is called teleological Consciousness (end), and in the science of religion called the consciousness of Ruhaniyah.

\section{Compassion}

Compassion, according to Abdullah Nashih Ulwan, can mean meekness and sensitivity of affection towards others. ${ }^{10}$ In the process of teaching and learning, the affection should be the basis of the process of transferring value and knowledge. Without affection, the learning process will only be the routine that gives birth to the generation of "numbness", which only understands how to apply the knowledge rationally, without using the emotional dimension (sense) as a human.

In the context of the Prophet Ibrahim's story, the values of affection shaped : First, compassion for parents. The Prophet Ibrahim's invitation to his father to meet, in fact, was the realization of the child's affectionate form of parents. The Prophet Ibrahim realized that life was not just once. Second, compassion for his son and posterity. Things can be seen in the QS alBaqarah (2): 124 and QS. Ibrahim (14): 40. Third, compassion for the people. Compassion for the people as affectionate to his father is realized in the form of a call to them to Bertawhid. Another form of affection of the US prophet Ibrahim to the people is the prayer of salvation of all mankind is done as in (QS. Al-Baqoroh: 129). The prayer expressed by Prophet Ibrahim AS A very show of concern to others. Prophet Ibrahim AS wanted to want the might and the policy of God can send an apostle who can purify those who still can not acknowledge the tawheed so that there must be a figure present to read the verse Allah SWT (Jalaludin: 19). ${ }^{11}$

\section{Patience}

In the context of the Prophet Ibrahim's story, there are at least three phases of struggle in the life of prophet Ibrahim as requiring high level of patience. First, attempts to find the right beliefs (Tauhid). Second, fighting for the creed and dealing with Namrud. As a prophet, Ibrahim invited his people to worship God who created the heavens and the earth. He continued to do an argumentative dialogue to convince his people. But most of them stick to the teaching

\footnotetext{
${ }^{10}$ Abdullah Nashih Ulwan, Pendidikan Anak Dalam Islam; Pendidikan Sosial Anak, (Bandung: Remaja Rosda Karya, 1996), Cet. 3, hlm. 11

${ }^{11}$ Jalaludin Muhammad Bin Ahmad Mahali dan Jalaludin 'abdurrahman bin Abi Bakar as-Suyuti, Tafsir al-Qur'an alKarim al-Jalilain al- Imamain, (Semarang : al-'alawiyah. Tt), hlm. 19

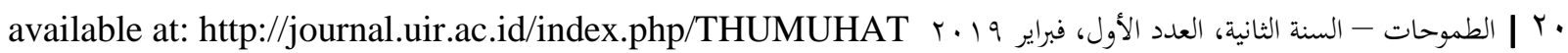


of his fathers. Addressing the condition, Prophet Ibrahim The US made a tactic to make his people aware. One when he entered the monastery where the statues were gathered and adored. It destroys the statues in pieces, except that the greatest is left intact to lure them to ask. But the effort that was impressed by the "violence" did not produce a glorious outcome. Ibrahim who has been suspected and his climax is he was punished with burnt alive. They also burned Ibrahim's body between the piles of firewood. The patience that is so strong on Ibrahim's chest does not make him recede establishing truth, despite the lives of his stakes. Again the bitter patience is fruitful sweet results. The fire that burned his nature suddenly came out of his law; Fire heat and burn wood, but does not burn Ibrahim's body (QS. Al-Anbiya '/21:52-70). The fire that is a creature of God that is always subject to the law of God immediately obeys God's order to cool and save Ibrahim's body, because the Prophet Ibrahim was a devout God.

Third, be patient when wanting a child. Almost a century old prophet Ibrahim, but he had not yet conferred a child. Because of the magnitude of the wishes, he also followed the wishes of his wife, Siti Sarah, to marry his maid, Siti Hajar. For Ibrahim, two wives were not by orgasm, but wanted the descendants of a Shaleh, which would hopefully continue his struggle in enforcing the religion of Tawhid. Allah also conferred a child with Halim character (QS. AlShaffat 101), named Isma'il. However, the son of the twentieth year of birth, when it appears that his glorious nature again intelligent, Allah instead tested the love of the Prophet Ibrahim; Whether more loving Isma'il or his lord? Allah ordered Ibrahim to slaughter Ibrahim through his dream (QS. Al-Shaffat/37:102). A very spiritual shaking test; Difficult to do by parents anywhere. Patiently, Ibrahim exercised the commandment in favor of his love for God. But his love for God is not wasted. Before the slaughter occurred, God replaced the body of Isma'il with a slaughter (Kibas/goat). This event became a charity that was prescribed to the people of Muhammad in the form of slaughter of sacrificial animals in the month of Haji.

The three phases of the struggle of Prophet Ibrahim as above are indeed the heavy trials that God has given him. However, with the faith and patience possessed by the Prophet Ibrahim, the struggle was fruitful results. This is what God promised to those who have faith again patiently, they bestowed salvation, compassion (mercy), and hidayah.

\section{Providing a model}

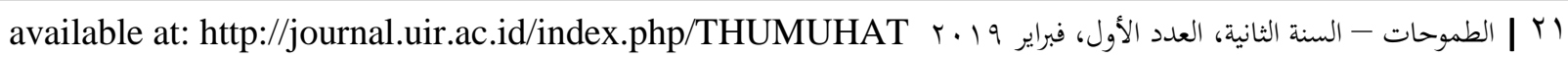


In the context of the Prophet Ibrahim's story, the example of Prophet Ibrahim appears on his personal figure as the figure of a child, father, and Servant of God. As a child, prophet Ibrahim was very respectful and love to his parents. The tribute was seen when he never disrupted his father's "profession" as a chisel or sculpture maker. Only, the problem is why the statues made by the man Koq were made as a idol (idols) 53 and considered as his lord. His love for parents appeared when the Prophet Ibrahim was always a prayer of mercy for his father because he was a good man (QS. 19:47).

The figure of a father seemed to the love and longing of the prophet Ibrahim to his son, the Prophet Ismail. Although the Prophet Ismail was far away there (in Mecca), but the prophet Ibrahim did not lose his love for the Prophet Ismail. In fact, when the Prophet Ismail had a family, his attention and affection to the Prophet Ismail always had a place in his heart.

As the figure as a servant of God, it appears from obedience in the command of God, persistence in the struggle to set the religion of Tauhid, and patience in the face of all odds of challenges and threats faced by him. In the context of this patience, God commanded us to emulate the "model" patience of the Prophets Ulul Azmi (Prophet Nuh, Prophet Ibrahim, Prophet Musa, Prophet Isa and Prophet Muhammad SAW), as stated in the QS al-Ahqaf (46): 35.

\section{Democracy}

In the context of Islamic education, a democratic education is essentially an education that develops the principal of democracy, which is an educational pattern that respects the difference of opinion (the right to be different), the freedom to Actualisas Self-fish, intellectual freedom, the opportunity to compete in self realization, moral education, and an education that draws closer to his creator. ${ }^{12}$

In the context of the Prophet Ibrahim's story, democratic values appear, such as the dialogue between the Prophet Ibrahim and the Little prophet Ismail when the Prophet Ibrahim intends to kill him. Here it appears that the values of democracy (equality, freedom, tolerance) are completely actualized in the life of the Prophet Ibrahim. The equality of obligation is also established in life when he invites his father to religious tawhid. Here it appears that the Prophet Ibrahim treat the same between his father and his people as the object of da'wah that

\footnotetext{
${ }^{12}$ Tilaar, Multikultural Tantangan-Tantangan Global Masa Depan dalam Transformasi Pendidikan Nasional, (Jakarta : Grasindo, 2004), hlm. 297-298

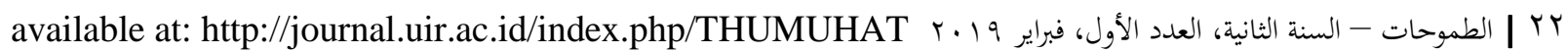


must be exercised by him indiscriminately, because religious proselytizing is the obligation of God.

Other democratic values, in the story of the Prophet Ibrahim is a method of da'wah in a peaceful, nonviolent manner. Although the Prophet Ibrahim, for example, had the power to fight them, because every prophet must have miracles, but the Prophet Ibrahim chose in a way of peace and a dialogical atmosphere.

\section{CONCLUSION}

Based on explanation above, it can be concluded as follows:

1. Many of the lessons from the way of prophet Ibrahim to us who expect a similar position, for personal or family, it is a necessity for us to follow every step of his travels, as the appeal God.

2. The values of Islamic education found in the story of Prophet Ibrahim AS consist of Akhlaq values consisting of: honesty (Shiddiq), Trusted (trust), Submission of Truth or Tabligh, Intelligence or Fathanah, affection, and democracy.

Based on the above conclusion, then through this writing, we recommend to other researchers to do similar research, for example education management is another perspective of Prophet Ibrahim and so on. Hope that we really dive into the ocean of knowledge in the Quran, according to the capabilities.

\section{REFERENCES}

Al-Jurjani \& al-Ta’Rifat. Beirut: dar al-kutub al-Ilmiyah. 1988.

al-Zarnuji, Burhan al-Islam. Ta'lim al-Muta'allim Thariq al-Ta'allum. Surabaya: Salim Nabhan. tt.

Attabik Ali dan A. Zuhdi Muhdlor. Kamus Kontemporer Arab Indonesia. Yogyakarta: Multi Karya Grafika. 1998.

Hasan, Zainol. "Nilai-Nilai Pendidikan Pada Kisah Nabi Ibrahim", Nuansa, Vol. 14 No.2 Juli, Desember. 2017.

http://midwiferyenterpreneurship.blogspot.co.id/2013/09/fathanah-nabimuhammad-sawseorang.html, dikutip pada 21 Desember 2019 pukul 19:45.

https://www.hidayatullah.com/kajian/oase-iman/read/2018/08/23/149161/tiga-karakter-mendasarkemuliaan-keluarga-ibrahim.html, dikutip pada 21 Desember 2019 pukul 19:20.

available at: http://journal.uir.ac.id/index.php/THUMUHAT r r ب أطموحات - السنة الثانية، العدد الأول، فبراير 19 
Jalaludin Muhammad Bin Ahmad Mahali dan Jalaludin 'abdurrahman bin Abi Bakar as-Suyuti. Tafsir al-Qur'an al-Karim al-Jalilain al-Imamain. Semarang : al-'alawiyah. TT.

Manajemen Nabi Ibrahim AS Oleh Ustadz H.Hendri Tanjung, Ph.D, dikutip dari youtube pada 21 Desember 2019 pukul 15:00.

Muhaimin \& Abdul Mujib. Pemikiran pendidikan Islam. Bandung: Rosdakarya. 1993.

Pendidikan keagamaan Islam, seperti Taman Pendidikan al-qur'an, Diniyah dan Pesantren tertera dalam UU No. 20 Tahun 2003 Tentang Sistem Pendidikan Nasional dan Peraturan Pemerintah No. 55 Tahun 2007 Tentang Pendidikan Islam dan Pendidikan Keagamaan Islam. Lihat UU No. 20 Tahun 2003 Tentang Sistem Pendidikan Nasional,"n,d.

Tilaar. Multikultural Tantangan-Tantangan Global Masa Depan dalam Transformasi Pendidikan Nasional. Jakarta : Grasindo. 2004.

Ulwan, Abdullah Nashih. Pendidikan Anak Dalam Islam; Pendidikan Sosial Anak. Bandung: Remaja Rosda Karya. Cet. 3. 1996. 